\title{
New biosorbent in removing some metals from industrial wastewater in El Mex Bay, Egypt
}

\author{
Maha Ahmed Mohamed Abdallah ${ }^{1} \cdot$ Mohamed E. Mahmoud $^{2} \cdot$ Maher M. Osman $^{2}$. \\ Somaia B. Ahmed ${ }^{1}$
}

Received: 3 April 2015/Accepted: 13 December 2015/Published online: 28 December 2015

(c) The Author(s) 2015. This article is published with open access at Springerlink.com

\begin{abstract}
Biosorption is an extensive technology applied for the removal of heavy metal ions and other pollutants from aqueous solutions. In the present study, the biosorption of cadmium, lead, chromium and mercury ions from polluted surface seawater in El-Max Bay was determined using hybrid active carbon sorbents. These sorbents were treated chemically by acid, base and redox reaction followed by surface loading of baker's yeast biomass for increasing their biosorption capacity and the highest metal uptake values. The surface function and morphology of the hybrid immobilized sorbents were studied by Fourier Transform Infrared analysis and scanning electron microscope imaging. Metal removal values proved that the vital role of baker's yeast as a significant high removable due to functional groups at baker's yeast cell wall surface that have the ability to forming various coordination complexes with metal ions. A noticeable increase in the removal of all studied metals was observed and reached to $100 \%$.
\end{abstract}

Keywords Activated carbon - Baker's yeast .

Wastewater · El Mex Bay · Egypt

\section{Introduction}

The metal contaminations in the aquatic environments have received considerable concern due to their toxicity, abundance and persistence in the environment, and their

Maha Ahmed Mohamed Abdallah

mahaahmed72007@Yahoo.com; mahaahmed7@ymail.com

1 Marine Pollution Lab, National Institute of Oceanography and Fisheries, Qait Bey, Alexandria, Egypt

2 Chemistry Department, Faculty of Sciences, Alexandria University, Alexandria, Egypt subsequent accumulation in aquatic habitats. It has been recognized for many years that the concentrations of metals found in dissolved or particulate phase of coastal areas, may be derived from a variety of anthropogenic and natural sources (Abdallah et al. 2007). El-Mex Bay is a part of Alexandria coast on the Mediterranean Sea, it is adjacent to Alexandria City center that is populated with about six million inhabitants; in addition, it is considered as one of the main fishing sources in Egypt (Abdallah 2014). The contaminants are introduced through waterway and through several landbased sources into the Bay. El-Mex Bay has several industrial plants situated close to the coast and directly discharges its effluents into it. In addition this Bay is an estuarine zone of huge agricultural drain (Omoum Drain), which crosses areas of intensive agriculture and a county with rapidly growing population density, and industrial activities; its discharge rate is about $2547.7 \times 10^{6} \mathrm{~m}^{3} /$ year (Abdallah 2008; El-Rayis and Abdallah 2006). As a result, large amounts of pollutants including heavy metals were supplied to the bay. Besides aquatic inputs, El-Mex Bay is also exposed to atmospheric pollution from the same activities that cause aquatic pollution.

Removal of heavy metals can be mainly accomplished using various conventional methodologies which are generally known as inefficient and/or expensive especially at low metal concentrations (Abdallah 2008). Adsorption is one of the most efficient techniques for heavy metal removal, extraction and pre-concentration of low concentration levels from various aqueous and non-aqueous matrices (Mahmoud et al. 2010; Abdel-Fattah et al. 2014). A number of carbonaceous materials have been used and applied as sorbents due to their easy handling and high adsorption efficiency for water purification and waste water treatment of hazardous materials including organic and 
heavy metal species (Mahmoud et al. 2008; Tian et al. 2010; Faur- Brasquet et al. 2002; Mahmoud et al. 2012). The adsorption efficiency of active carbon sorbent toward heavy metals can be enhanced and improved by surface modification via immobilization and incorporation of certain chelating functional groups.

On the other hand, baker's yeast, known as Saccharomyces cerevisiae, is characterized by the presence of various chelating functional groups that were deployed in successful biosorption and removal of heavy metal ions such as $\mathrm{Cr}(\mathrm{III}), \mathrm{Cr}(\mathrm{VI}), \mathrm{Hg}(\mathrm{II}), \mathrm{As}(\mathrm{III})$ and As(v) from aqueous samples (Bag et al. 1998; PeezCorona et al. 1998; Yavuz et al. 2006; Bag et al. 2002). These procedures were implemented using immobilized baker's yeast on several solid matrices such as silica gel, Dowex anion exchanger and other solid supports (Mahmoud et al. 2011; Baccara et al. 2009). In this study, a method was established and presented to enhance and improve the adsorptive efficiency of active carbon for pre-concentration of some toxic heavy metals such as $\mathrm{Cd}, \mathrm{Pb}, \mathrm{Cr}$, and $\mathrm{Hg}$ from aqueous solutions by simple, direct and affordable chemical treatment and biological immobilization of baker's yeast, as a source of chelating functional groups. The metal-sorbent interaction processes and mechanisms were investigated in this study using FT-IR analysis which characterized the surface functional groups of the studied hybrid Ac sorbent-biosorbent.

\section{Materials and methods}

\section{Study area}

El-Mex bay bordering an industrial zone is located west of Alexandria City, one of the most densely populated cities with 6 million people. This bay extending for about $7 \mathrm{~km}$ between longitude $29^{\circ} 45^{\prime}$ and $29^{\circ} 54^{\prime} \mathrm{E}$ and latitude $31^{\circ} 07^{\prime}$ and $31^{\circ} 15^{\prime} \mathrm{N}$ (Fig. 1), from Agami headland (west) to the Western Harbor (east), occupies an area of $19.4 \mathrm{~km}^{2}$ with a mean depth of $10 \mathrm{~m}$ and a water volume of $190.3 \times 10^{6} \mathrm{~m}^{3}$ (Abdallah et al. 2007). As a consequence of growing heavy industries (chloroalkali, cement, chemicals, textile, tanneries, industrial dyes, ink, petroleum refining, meat processing, fish production, and iron or steel industries) and the uncontrolled disposal of resulting wastes, the coastal water of El-Mex Bay receives huge amounts of untreated industrial wastes containing heavy metals like $\mathrm{Hg}, \mathrm{Cr}, \mathrm{Cd}$ and $\mathrm{Pb}$ dumped directly into the southern part of the bay via pipelines. In addition, El-Dekhaila Harbor (commercial harbour) has been recently constructed at the western side of El-Mex Bay.

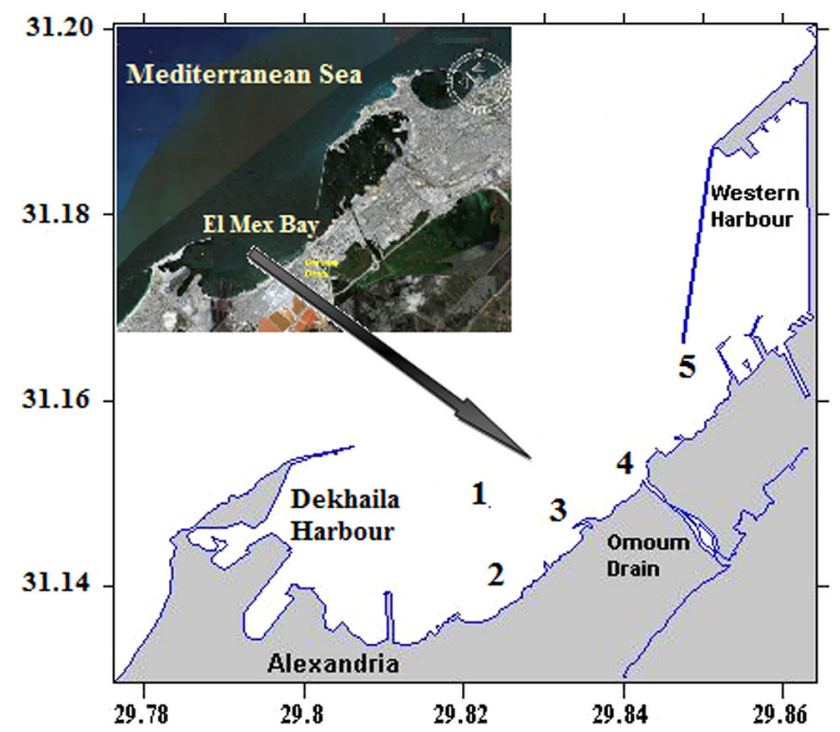

Fig. 1 Study area of El-Mex Bay

\section{Sampling}

Surface water samples were collected from five stations during June 2014, to provide a broad spatial coverage of the bay and allow assessment of the water quality throughout the Bay. The bay has been divided into two parts (inshore and middle regions). The inshore part represents the discharging points of different sources (stations 2, 3 and 4), heavily polluted by unauthorized discharges of industrial effluents. The middle part covers stations 1 (closed to the ethylene platform) and 5 (the entrance of the Western Harbour). Study area and positions of sampling stations are shown in Fig. 1. All the surface water samples, from all studied areas, were collected by hand from a rowing boat by submerging precleaned PE $(5 \mathrm{~L})$ bottles approximately $20 \mathrm{~cm}$ beneath the water surface. Procedural blanks were prepared in the same way as samples, and none of the target metals was detected.

\section{Synthesis of hybrid active carbon-immobilized- baker's yeast sorbents}

Commercial activated carbon (AC) was weighed and treated by $\mathrm{HCl}$ and stirred for $4 \mathrm{~h}$ to produce sorbent acid treated activated carbon (AT-AC). A normal weight of (AT-AC) sorbent was added to baker's yeast and the reaction mixture was mixed well and dried in an oven. Base treated active carbon (BT-AC) sorbent and base treated active carbon-immobilized-baker's yeast (BT-AC-BY) sorbent were also prepared in a similar way using $\mathrm{NaOH}$. Oxidized active carbon sorbent (Ox-AC) sorbent and oxidized active carbonimmobilized-baker's yeast sorbent (Ox-AC-BY) were also prepared in a similar way using $\mathrm{HNO}_{3}$ as an oxidizing agent.

Reduced active carbon (Rd-AC) sorbent and reduced active carbon-immobilized-baker's yeast sorbent (Rd-AC-BY) 
Table 1 Hybrid chemically and biologically treated active carbon sorbents

\begin{tabular}{|c|c|}
\hline $\begin{array}{l}\text { Symbol } \\
\text { sorbent }\end{array}$ & Active carbon \\
\hline $\mathrm{AC}$ & Active carbon-modified-baker's yeast \\
\hline AC-BY & Active carbon-immobilized-baker's yeast \\
\hline AT-AC & Acid-treated-active carbon \\
\hline AT-AC-BY & Acid treated active carbon- immobilized -baker's yeast \\
\hline BT-AC & Base treated active carbon \\
\hline BT-AC-BY & Base treated active carbon- immobilized -baker's yeast \\
\hline Ox-AC & Oxidized active carbon by nitric acid \\
\hline Ox-AC-BY & $\begin{array}{l}\text { Oxidized active carbon by nitric acid and immobilized } \\
\text { by baker's yeast }\end{array}$ \\
\hline $\mathrm{Rd}-\mathrm{AC}$ & Reduced active carbon by sodium sulfite \\
\hline $\mathrm{Rd}-\mathrm{AC}-\mathrm{BY}$ & $\begin{array}{l}\text { Reduced active carbon by sodium sulfite and } \\
\text { immobilized by baker's yeast }\end{array}$ \\
\hline
\end{tabular}

were also prepared in a same manner using $\mathrm{Na}_{2} \mathrm{SO}_{3}$ solution as reducing agent (Grote and kettrup 1985). The list and specifications of all hybrids chemically and biologically modified active carbon biosorbents are given in Table 1.

\section{Analysis}

\section{Dissolved heavy metals}

In the laboratory, water samples were filtered through 0.45$\mu \mathrm{m}$ membrane filter. The filtered samples (dissolved phase) were acidified using nitric acid and trace metals were preconcentrated and measured using Atomic Absorption Spectrophotometry the procedures adopted followed (Abdullah and Royle 1974). Samples were analyzed using an air-acetylene flame atomic absorption spectrophotometer Shimadzu Model AA-6800, Duisburg, Germany, with D (subscript 2) background correction and an autosampler. Results were expressed as micrograms of element per liter of water samples. All absorbance readings were made in triplicate. Instrument settings were as recommended in the manufacturer's manual, with wavelengths (nm) of 228.8, 357.9 and 283.31 for $\mathrm{Cd}, \mathrm{Cr}$ and $\mathrm{Pb}$ respectively. For $\mathrm{Hg}$ analysis, a cold vapor atomic absorption spectrophotometer flow injection $\mathrm{Hg} /$ hydride analyzer (MVu 1A-Mercury vaporizer unit) was used with wavelength of $253.7 \mathrm{~nm}$ and a quartz absorption cell was used for the metals determination according to the
United Nations Environment Programme (UNEP 1993). The accuracy and analytical procedures were verified by analyzing a certified reference material (LGC-6010). All trace elements gave both accurate and precise results.

\section{Potential of hybrid active carbon sorbents for removal of heavy metals from water samples}

Surface functionality of carbon sorbents is characterized by its responsibility for all activity and reactivity as well as capability for all adsorption properties and processes. In this work, infrared spectroscopy was used to obtain information about the chemical structure and functional groups of the raw material and the hybrid activated carbon biosorbents. The FTIR spectrum were recorded using a Shimadzu Fourier Transform infrared spectrophotometer (FTIR system-BX 0.8009 ) was used in the range $200-4000 \mathrm{~cm}^{-1}$ to acquire the FT-IR spectra of all chemically and biologically treated active carbon sorbents. These sorbents were also imaged by the use of scanning electron microscope (JSM-5300, JEOL Ltd.). An ion sputtering coating device (JEOL-JFC-1100E) was used to coat the SEM specimens with gold to increase the conductivity. The Brunauer, Emmett and Teller (BET) technique is the most common method for determining the surface area of powders and porous materials. Nitrogen gas is generally employed as the probe molecule and is exposed to a solid under investigation at liquid nitrogen conditions (i.e. $77 \mathrm{~K}$ ). The surface area of the solid is evaluated from the measured monolayer capacity and knowledge of the crosssectional area of the molecule being used as a probe. For the case of nitrogen, the cross-sectional area is taken as 16.2 A2/molecule. Malvern Zetasizer Nano ZS90 was used to measure the particle size and the zeta potential of active carbon sorbents microspheres.

Pre-concentration of heavy metals was performed according to the following procedure. The wastewater samples were passed over a pre-concentration micro-column with a diameter of $30 \mathrm{~mm}$ and length: $70 \mathrm{~mm}$ packed with $50 \mathrm{mg}$ (pack length: 5-7 mm) of the modified hybrid active carbon sorbents with a flow rate of $10 \mathrm{ml} \mathrm{min}{ }^{-1}$ under air pressure. The adsorbed metal ions on the hybrid active carbon sorbents surface was eluted by the flow of $5.0 \mathrm{ml}$ of conc. $\mathrm{HNO}_{3}$ and determined by atomic absorption spectrophotometer, all values are triplicate (Grote and Kettrup 1985). The removal percentages were calculated as:

Removal $\%=\frac{\text { Detected concentration of sample after passing over sorbent }}{\text { Initial concentration of sample before passing over the sorbent }} \times 100$. 
Fig. 2 FT-IR spectra of hybrid activated carbon sorbents

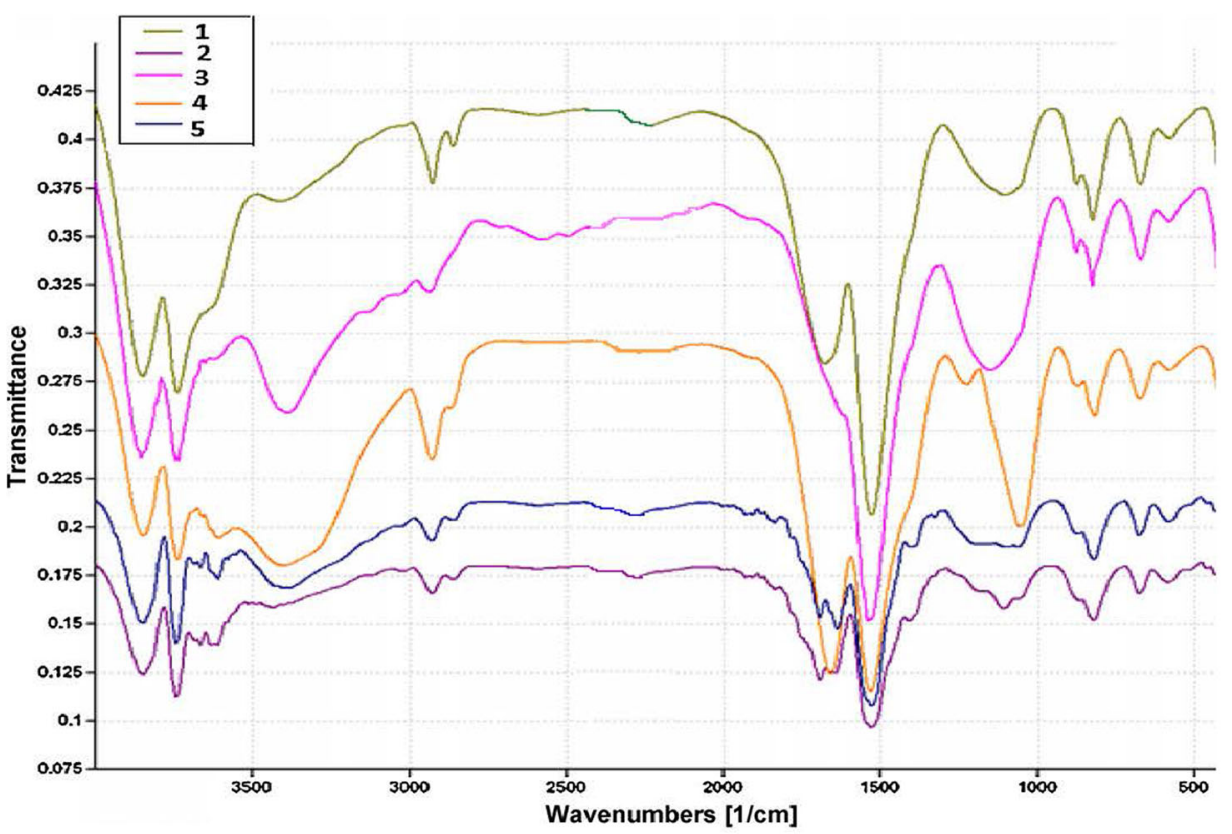

(1) AC, (2) AT-AC, (3) BT-AC, (4) Ox-AC, (5) Rd-AC

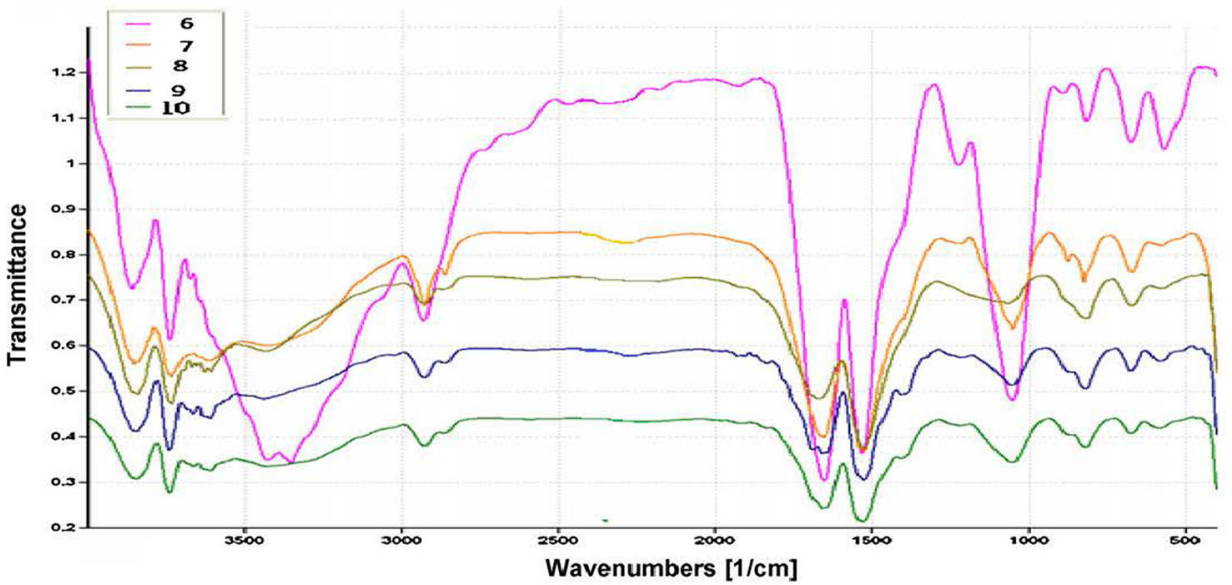

(6) AC-BY, (7) AT-AC-BY , (8) BT-AC-BY, (9) Ox-AC-BY, (10) Rd-AC-BY

\section{Results and discussion}

\section{Surface characterization}

The surface functional groups of the tested sorbent and biosorbents system were determined and characterized by FT-IR analysis. The infrared spectroscopy is a commonly used technique to figure out the various functional groups as well as to find information about the surface activity of chemically and biologically hybrid active carbon sorbents. Characteristics of infrared peaks are mainly identified and related to the nature of $\mathrm{AC}$ sorbent as shown in Fig. 2. However, upon chemical treatments using acid-base and redox reactions as well as surface immobilization of baker's yeast, several other IR peaks were produced. The peak centered at $1110-1120 \mathrm{~cm}^{-1}$ is mainly due to $(\mathrm{C}-\mathrm{O})$ of methoxy group and the strong peak appearing at 1520 and $1670 \mathrm{~cm}^{-1}$ are mainly ascribed to the formation of oxygen functional groups based on highly conjugated $\mathrm{C}-\mathrm{O}$ stretching in carboxylic or carboxylate group as well as carbonyl group. The broad band in the region $3300-3600 \mathrm{~cm}^{-1}$ is typically attributed to O-H stretching or adsorbed water molecule. Thus, chemical and biological treatment processes of $\mathrm{AC}$ sorbent were found to improve and intensify the various functional groups of AC sorbent.

Scanning electron microscopy (SEM) is known as an efficient technique for investigation and evaluation of the surface morphology of modified sorbents, Fig. 3 represents the SEM-image of untreated AC sorbent and all treated AC forms, respectively. The surfaces of the chemically treated 
Fig. 3 Scanning electron micrograph of hybrid activated carbon sorbents

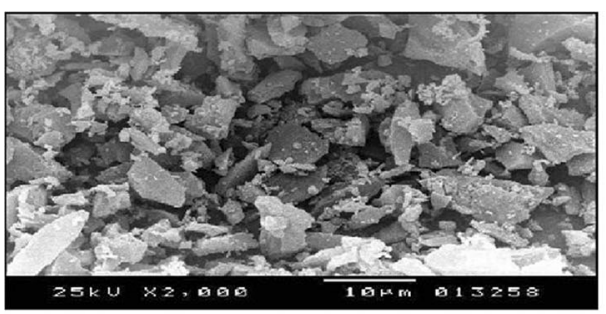

(a) SEM-Image of AC

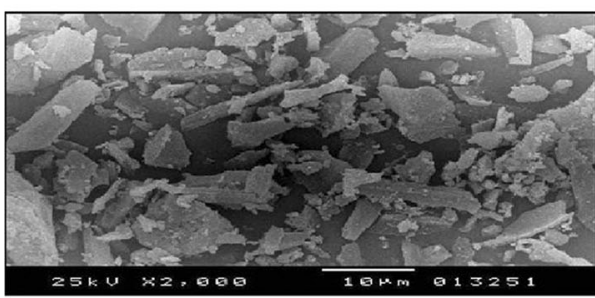

(b) SEM-Image of AT-AC

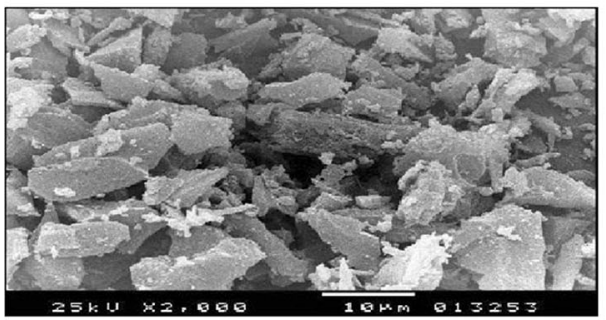

(c) SEM-Image of BT-AC

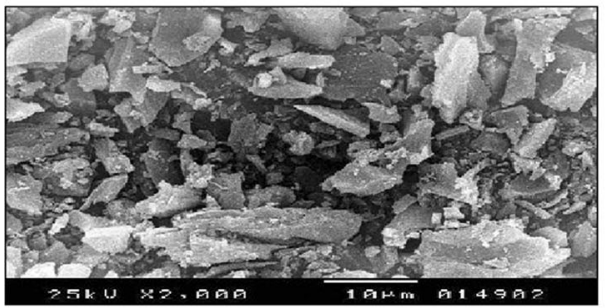

(d) SEM-Image of Ox-AC

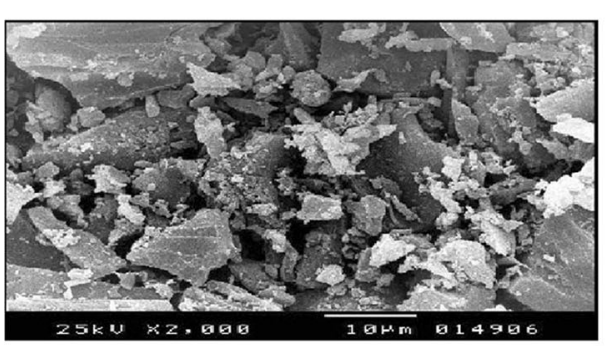

(e) SEM-Image of Rd-AC

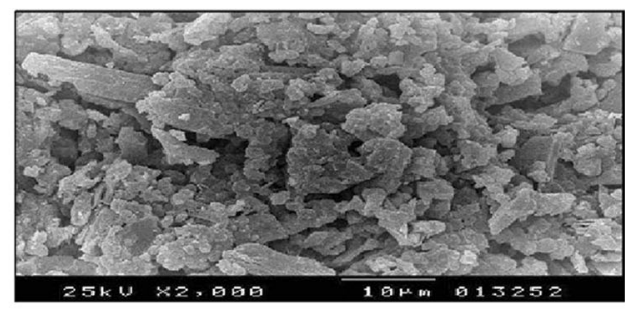

(f) SEM-Image of AT-AC-BY

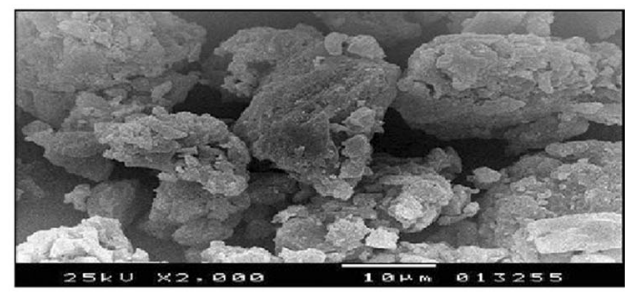

(g) SEM-Image of Rd-AC

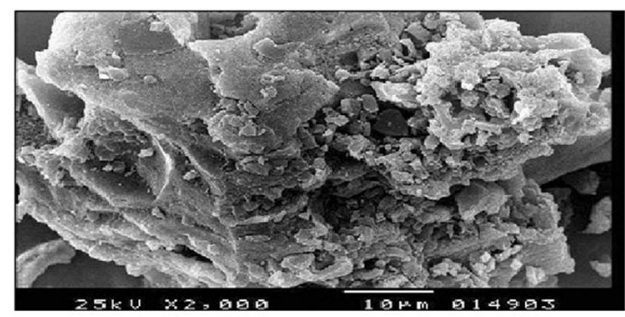

(h) SEM-Image of OX-AC-BY

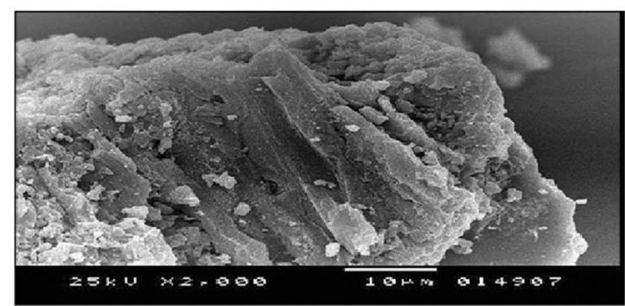

(i) SEM-Image of Rd-AC-BY 
Fig. 4 Specific area characters of AC-BY by BET analysis

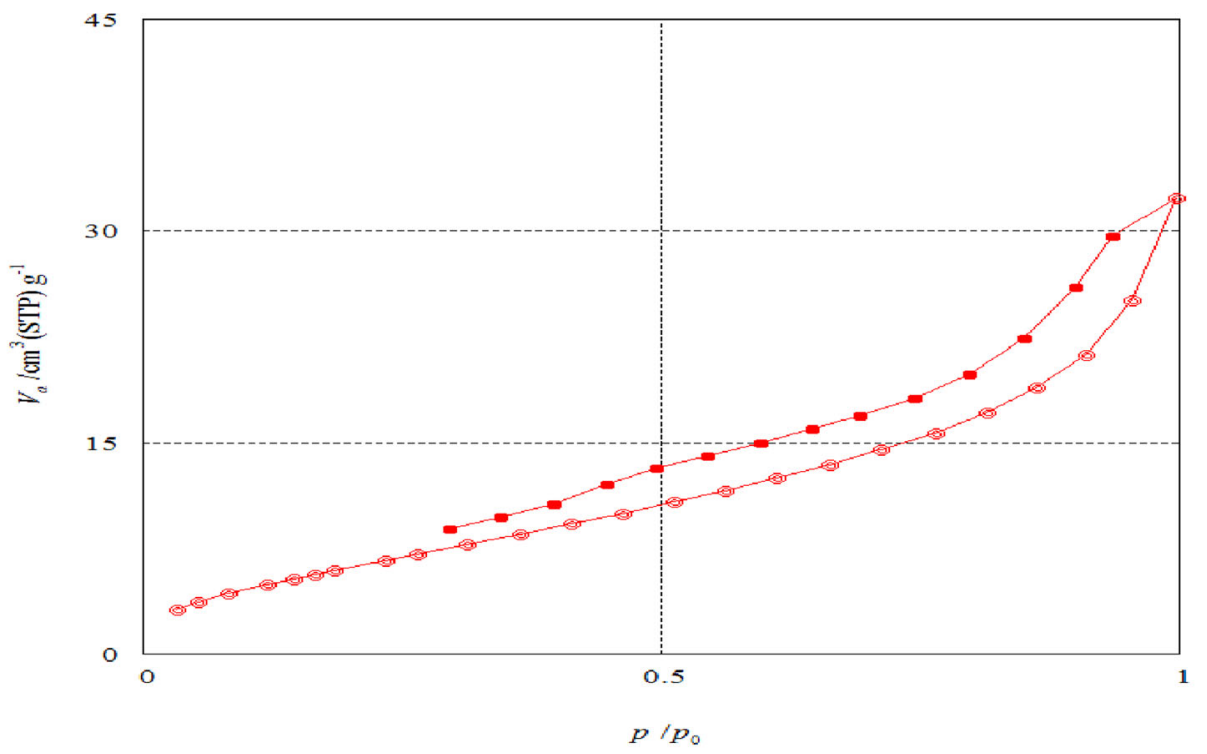

Adsorption / desorption isotherm Adsorptive N2

Adsorption temperature77.000[K]
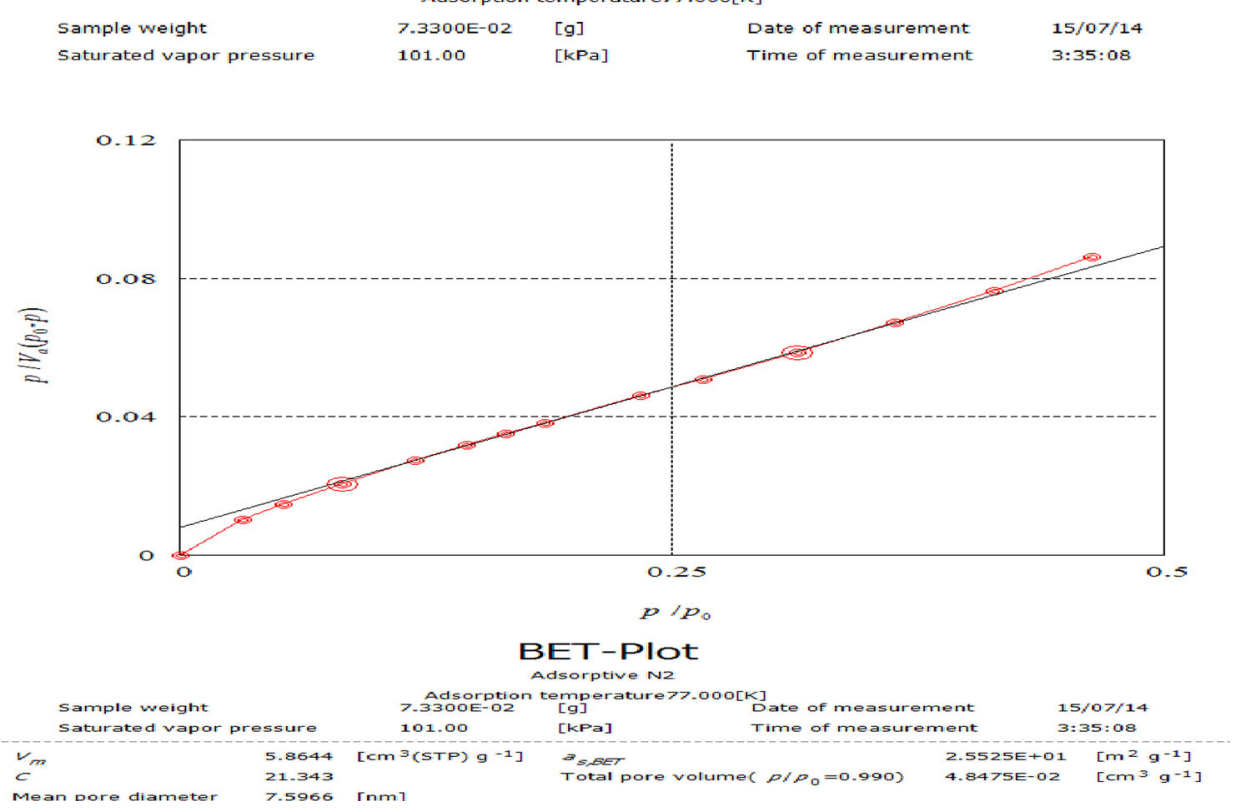

isotherm and the pore size distribution curve of the sorbents microspheres are also provided as contrast, as shown in Figs. 4 and 5. The BET surface area of the hollow sorbent Rd- AC-BY is $1.2927 \mathrm{E}+02 \mathrm{~m}^{2} / \mathrm{g}$, which is larger than that of AC-BY sorbent $\left(2.5525 \mathrm{E}+01 \mathrm{~m}^{2} / \mathrm{g}\right)$, and the total pore volume $\left(0.1524 \mathrm{~cm}^{3} / \mathrm{g}\right)$ of $\mathrm{Rd}-\mathrm{AC}-\mathrm{BY}$ is also larger than that of AC-BY sorbent $\left(4.8475 \mathrm{E}-02 \mathrm{~cm}^{3} / \mathrm{g}\right)$. Furthermore, the mean pore diameter of AC-BY $(7.5666 \mathrm{~nm})$ is slightly large compared with Rd-AC-BY $(4.7155 \mathrm{~nm})$ sorbent which own a much richer porous structures, as shown in the inset of Fig. (5). The pre-concentration results indicates that adsorbent materials owning relatively high specific surface area, high porous volume and hollow structure will show a better adsorption ability, as these pore structures can provide more adsorption sites (Cui et al. 2015; Fu et al. 2015).

\section{Removal of metals by different forms of the modified AC}

Removal of Cd from wastewater samples of El-Max bay by hybrid AC sorbents

Removal of dissolved cadmium from industrial wastewaters by sorption or biosorption, as one of the most effective processes, was always planned and aimed. The traces 
Fig. 5 Specific area characters of Rd- AC-BY by BET analysis

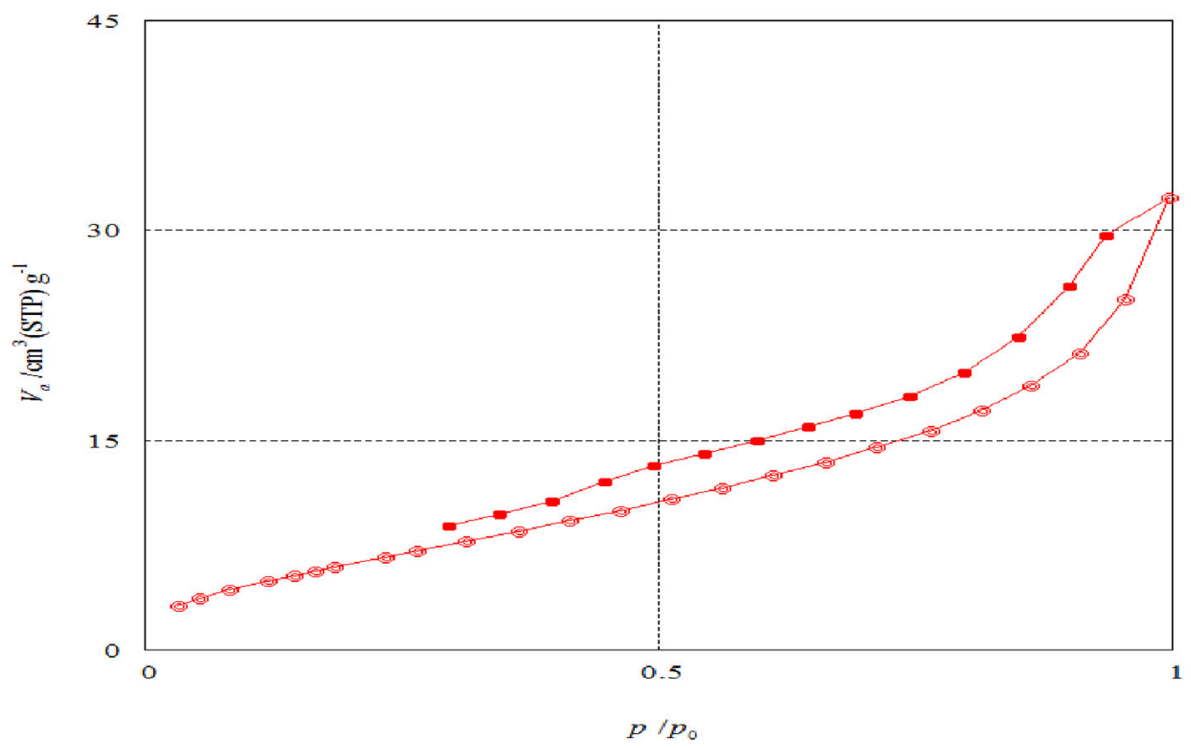

Adsorption / desorption isotherm Adsorptive N2 Adsorption temperature77.000[K] $\begin{array}{lllll}\text { Sample weight } & 7.3300 \mathrm{E}-02 & {[\mathrm{~g}]} & \text { Date of measurement } & 15 / 07 / 14 \\ \text { Saturated vapar pressure } & 101.00 & {[\mathrm{kPa}]} & \text { Time of measurement } & 3: 35: 08\end{array}$

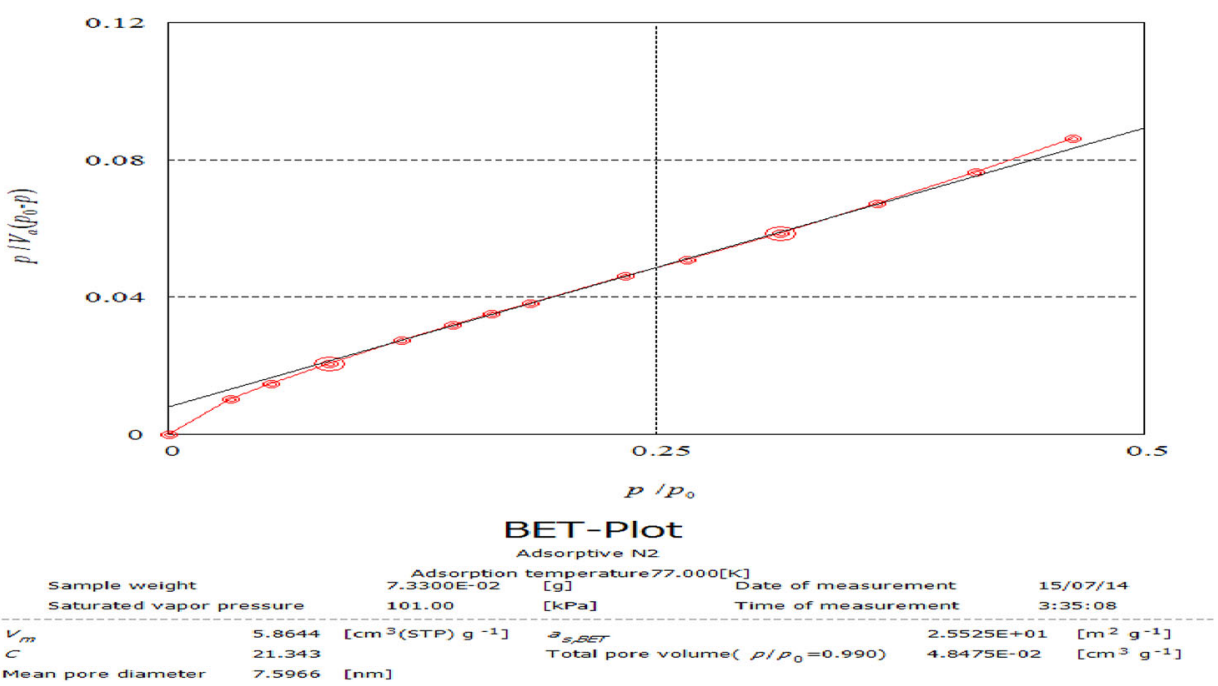

existence of $\mathrm{Cd}$ and other heavy metals in El-Mex bay leads to use pre-concentration technique as judging on the capacity of hybrid AC sorbents as a removal of cadmium ion. Therefore, the surface water samples were collected from five stations in El-Mex Bay and pre-concentrated for $\mathrm{Cd}$ via a multistage micro-column technique. The data show that the highest concentration $(0.251 \mu \mathrm{g} / \mathrm{L})$ was at station No. 5, at the iterance of the Western Harbour (Fig. 1), while the lowest contaminated areas were at stations 3 and $4(0.051$ and $0.077 \mu \mathrm{g} / \mathrm{L})$, respectively. Stations 1 and 2 show moderate contamination by $\mathrm{Cd}$ (II) 0.122 and $0.141 \mu \mathrm{g} / \mathrm{L}$, irrespectively. The results show that AC-treated-baker's yeast sorbents proved highly effective in the removal of the $\mathrm{Cd}$ than those of the chemically modified active carbon sorbents and both of these sorbents are generally higher than blank AC sorbent. The AC sorbent as a packing material in the micro-column was found to produce removal percentage values of $70-75 \%$ after the first run (first passing of each sample through micro-column) and 82-85\% after the second one (second passing of each sample through micro-column). On the other hand, AC-BY, AT-AC, AT-AC-BY, BT-AC,BT-AC-BY, Ox$A C$, Ox-AC-BY, Rd-AC and Rd-AC-BY were found to produce removal values in ranges of 90-94, 88-92, 95-99, 90-95, 97-100, 95-100, 100, 100 and $100 \%$ (Table 2), respectively, all stations. Considering the results we can 
Table 2 Removal of Cd (II) from wastewater samples of El-Max Bay

\begin{tabular}{|c|c|c|c|c|c|}
\hline \multirow[t]{2}{*}{ Sorbents } & \multicolumn{5}{|c|}{ Removal \% } \\
\hline & Station 1 & Station 2 & Station 3 & Station 4 & Station 5 \\
\hline $\mathrm{AC}$ & 85 & 84 & 82 & 82 & 85 \\
\hline AC-BY & 93 & 94 & 93 & 90 & 94 \\
\hline AT-AC & 92 & 91 & 88 & 90 & 92 \\
\hline AT-AC-BY & 99 & 99 & 96 & 95 & 99 \\
\hline BT-AC & 95 & 93 & 91 & 90 & 94 \\
\hline BT-AC-BY & 99 & 100 & 98 & 97 & 100 \\
\hline Ox-AC & 98 & 99 & 95 & 95 & 100 \\
\hline Ox-AC-BY & 100 & 100 & 100 & 100 & 100 \\
\hline Rd-AC & 100 & 100 & 100 & 100 & 100 \\
\hline Rd-AC-BY & 100 & 100 & 100 & 100 & 100 \\
\hline
\end{tabular}

find that,the three sorbents Ox-AC-BY, Rd-AC and RdAC-BY show the maximum removal of $\mathrm{Cd}$ (II) from all station by around $100 \%$ after one run only.

The heavy metal uptake is attributed to different mechanisms of ion-exchange processes and/or metal complex formation as well as to the adsorption process. During the ion-exchange process, metal ions had to move through the pores of the hybrid AC mass, but also through channels of the lattice, and they had to replace exchangeable cations. Diffusion was faster through the pores and was retarded when the ions moved through the smaller diameter channels. In this case the metal ion uptake could mainly be attributed to ion-exchange reactions in the micro porous minerals of hybrid AC mass (Erdem et al. 2004).

The other mechanism of metal uptake could be forming various coordination complexes between heavy metals and the functional groups on the hybrid AC sorbent surface from chemical and biological modification. The data point out that the obvious increasing of $\mathrm{Cd}$ removal in all five stations done by increasing the chemical treated of $\mathrm{AC}$, in order $\mathrm{AT}-\mathrm{AC}>\mathrm{BT}-\mathrm{AC}>\mathrm{Ox}-\mathrm{AC}>\mathrm{Rd}-\mathrm{AC}$. In another word the more donor atoms exist on the sorbent surface more binding sites available for directed interaction with metal ion. Further surface modification of AC, AT-AC, BT-AC, Ox-AC and Rd-AC sorbents via immobilization of baker's yeast for the formation of the corresponding hybrid carbon sorbents AC-BY, AT-AC-BY, BT-AC-BY, Ox-AC$\mathrm{BY}$ and Rd-AC-BY, respectively were studied and compared for metals binding and sorption interaction processes. In general, the metal removals values are prove the vital role of baker's yeast as a significant high removable due to functional groups at baker's yeast cell wall surface that have the capable of forming various coordination complexes with metal ions. The functional groups responsible for binding with heavy metal ions are generally in the form of carboxyl (-COOH), phosphate $\left(\mathrm{PO}_{4}^{-3}\right)$, amine $\left(-\mathrm{NH}_{2}\right)$, thiol (-SH), and hydroxyl (-OH) (Park and Kim 2005). Such noticed enhancement that cadmium sorption removal process are mainly due the contribution of both hybrid chemical and biological treatments of $\mathrm{AC}$ with $\mathrm{Cd}$ via coordination complex mechanism with minor role for ion exchange process.

Furthermore, all sorbents removal percentage increase as the concentration of $\mathrm{Cd}$ decreases in the collected samples due to exist of more available active sites on the sorbents surface, that trend excluded the samples from stations (3) and (4), which give removal values lower than the expected. That behavior could be explained by the existence of more sorbets in the samples to compete with $\mathrm{Cd}$ on the active sites of the sorbents or may be cause of the traces concentration of $\mathrm{Cd}$ in both stations decreases the chance of collation between cadmium ions and sorbents particles.

Removal of $\mathrm{Pb}$ from wastewater samples of El-Max bay by hybrid AC sorbents

The percentages of removal $\mathrm{Pb}$ from all five stations in the study area after two runs by AC sorbent as a packing material in a micro-column extraction were in range of 85-90 \%. In other evidence, the different forms of the modified sorbents:AC-BY, AT-AC, AT-AC-BY, BTAC, BT-AC-BY, Ox-AC, Ox-AC-BY, Rd-AC and Rd-AC-BY were found to produce removal values of $\mathrm{Pb}$ in range of 93-97, 88-94, 97-99, 88-94, 93-100, 90-100, 99-100, 90-100 and $100 \%$ for the same sorbents and biosorbents (Table 3). Two stations Nos. 3 and 5 were excluded from this trend and behavior when Ox-AC-BY, Rd-AC and Rd-AC-BY sorbents were applied for removal of $\mathrm{Pb}$ only in one run of micro-column enough to produce $100 \%$ pre-concentration.

It is evident that the chemical treatment of AC improves the adsorption of all tested sorbents and biosorbents; an 
Table 3 Removal of $\mathrm{Pb}(\mathrm{II})$ from wastewater samples of El-Max Bay

\begin{tabular}{|c|c|c|c|c|c|}
\hline \multirow[t]{2}{*}{ Sorbents } & \multicolumn{5}{|c|}{ Removal \% } \\
\hline & Station 1 & Station 2 & Station 3 & Station 4 & Station 5 \\
\hline $\mathrm{AC}$ & 85 & 89 & 90 & 88 & 89 \\
\hline AC-BY & 93 & 95 & 97 & 93 & 97 \\
\hline AT-AC & 88 & 89 & 94 & 89 & 92 \\
\hline AT-AC-BY & 97 & 97 & 99 & 97 & 99 \\
\hline BT-AC & 88 & 90 & 94 & 89 & 93 \\
\hline BT-AC-BY & 93 & 97 & 100 & 95 & 99 \\
\hline Ox-AC & 90 & 95 & 100 & 90 & 98 \\
\hline Ox-AC-BY & 99 & 99 & 100 & 100 & 100 \\
\hline Rd-AC & 90 & 95 & 100 & 92 & 100 \\
\hline Rd-AC-BY & 100 & 100 & 100 & 100 & 100 \\
\hline
\end{tabular}

increase in the percentage removal of $\mathrm{Pb}$ from the wastewater with increasing of chelating groups on the surface of hybrid AC was observed. Both the Ox-AC and $\mathrm{Rd}-\mathrm{AC}$ sorbents with high number of chelating groups (Ox$\mathrm{AC}\left(-\mathrm{NO}_{3}\right)$ and $\left.\mathrm{Rd}-\mathrm{AC}\left(-\mathrm{SO}_{3}\right)\right)$ shows higher removal percentage than those sorbent with less number of chelating groups (AT-AC $(-\mathrm{Cl})$ and BT-AC $(-\mathrm{OH})$ ). Accordingly, the addition of baker's yeast on surface of hybrid AC gives a significant role in improving the adsorption strength of all tested sorbents (Vasudevan et al. 2002; Imamoglu and Tekir 2008). In the present study, a noticeable increase in the removal of $\mathrm{Pb}$ was observed due to the presence of more available chelating sites on the surface of hybrid AC from different functional groups of yeast cell wall (such as amine $(-\mathrm{NH} 2)$, thiol $(-\mathrm{SH})$, and hydroxyl $(-\mathrm{OH})$ that are capable of forming various coordination complexes and/or ion exchange mechanisms with $\mathrm{Pb}$ ions. That evidence referring to the contribution of both chemical and biological treatments are responsible for providing huge number of biding sites available for chelating the metal ions on the surface of the hybrid sorbents and biosorbents.

\section{Removal of Cr from wastewater samples of El-Max bay by hybrid AC sorbents}

The ability of hybrid AC sorbents to remove total $\mathrm{Cr}$ from the study area in El-Max bay was further studied as the important step to explore the potential applications of hybrid AC sorbents and its results. Percentage recovery values of total $\mathrm{Cr}$ from station No. 4, as a highest contaminated area by $\mathrm{Cr}(2.260 \mu \mathrm{g} / \mathrm{L})$, in the range of 85-94\% for second run by hybrid AC sorbents: AC, AC-BY, AT-AC, AT-AC-BY, BTAC, BT-AC-BY, Ox-AC, Ox-AC-BY, Rd$\mathrm{AC}$ and Rd-AC-BY (Table 4). However, the percentage recovery values of the $\mathrm{Cr}$ from this station were in the range $88-100 \%$ by the hybrid AC sorbents. The same trend and behavior were also observed for $\mathrm{Cr}$ species in stations (5), more contaminated area by $\mathrm{Cr}(1.076 \mu \mathrm{g} / \mathrm{L})$, by hybrid AC sorbents. The percentage recovery values of $\mathrm{Cr}$ in this area were found to be in the range of $90-100 \%$ as determined by hybrid AC sorbents(AC, AC-BY, AT-AC, AT-AC-BY, BTAC, BT-AC-BY, Ox-AC, Ox-AC-BY, Rd-AC and RdAC-BY) respectively (Table 4$)$.

This trend were changed in the lowest contaminated areas by $\mathrm{Cr}$ species (Stations No. 1, 2 and 3), the recover percentage for $\mathrm{Cr}$ species were found in the range of 86-100 \% for station No. 1 and $87-100 \%$ for stations No. 2 and 3 by all hybrid AC sorbents. This recovery percentages show increase reaching the maximum recovery around $100 \%$ by all hybrid AC sorbents. This better trend excluded the Ox-AC, Ox-AC-BY, Rd-AC and Rd-AC-BY which needed only one run to reach $100 \%$ recovery percentage. Maximum metal uptake values of $\mathrm{Cr}$ were obtained for the best performance hybrid AC sorbents (Ox-AC and $\mathrm{Rd}-\mathrm{AC}$ ) in all examined station especially at the lower contaminated stations (1, 2 and 3). the high sorption capacity for $\mathrm{Cr}$ may be explained by enhanced the direct chelating between metal ions and functional groups such as $(-\mathrm{COOH},-\mathrm{NH}$ and $-\mathrm{OH})$ at the activated carbon surface and the activated carbon loaded with baker's yeast surface. The small size of $\mathrm{Cr}$ atom could be suitable for porous on the surface of hybrid AC sorbent that also enhance the capability of those sorbents and biosorbents for removal percent of $\mathrm{Cr}$ spices reach $100 \%$ in some case after only first run. This explanation agrees with result gain from the above two metals $(\mathrm{Cd}$ and $\mathrm{Pb}$ ), where we found that both small size atoms $\mathrm{Cr}$ and $\mathrm{Cd}$ show higher removal percent than the removal percent of the highest size $\mathrm{Pb}$ atom (Gupta et al. 2011).

\section{Removal of $\mathrm{Hg}$ from wastewater samples of El-Max bay} by hybrid AC sorbents

The recovery percentage of $\mathrm{Hg}$ from five locations in ElMax bay was performed using a multistage micro-column 
Table 4 Removal of Cr from wastewater samples of El-Max Bay

\begin{tabular}{|c|c|c|c|c|c|}
\hline \multirow[t]{2}{*}{ Sorbents } & \multicolumn{5}{|c|}{ Removal \% } \\
\hline & Station 1 & Station 2 & Station 3 & Station 4 & Station 5 \\
\hline $\mathrm{AC}$ & 92 & 94 & 93 & 85 & 90 \\
\hline AC-BY & 94 & 93 & 96 & 92 & 92 \\
\hline AT-AC & 92 & 91 & 94 & 89 & 90 \\
\hline AT-AC-BY & 97 & 96 & 96 & 95 & 95 \\
\hline BT-AC & 94 & 95 & 97 & 92 & 90 \\
\hline BT-AC-BY & 97 & 97 & 99 & 96 & 93 \\
\hline Ox-AC & 96 & 100 & 100 & 94 & 94 \\
\hline Ox-AC-BY & 100 & 100 & 100 & 100 & 100 \\
\hline Rd-AC & 98 & 100 & 100 & 97 & 98 \\
\hline Rd-AC-BY & 100 & 100 & 100 & 100 & 100 \\
\hline
\end{tabular}

Table 5 Removal of $\mathrm{Hg}$ from wastewater samples of El-Max Bay

\begin{tabular}{|c|c|c|c|c|c|}
\hline \multirow[t]{2}{*}{ Sorbents } & \multicolumn{5}{|c|}{ Removal \% } \\
\hline & Station 1 & Station 2 & Station 3 & Station 4 & Station 5 \\
\hline $\mathrm{AC}$ & 80 & 85 & 65 & 99 & 73 \\
\hline AC-BY & 90 & 91 & 72 & 100 & 78 \\
\hline AT-AC & 84 & 90 & 75 & 100 & 77 \\
\hline AT-AC-BY & 91 & 92 & 80 & 100 & 85 \\
\hline BT-AC & 89 & 90 & 78 & 100 & 84 \\
\hline BT-AC-BY & 91 & 94 & 84 & 100 & 89 \\
\hline $\mathrm{Ox}-\mathrm{AC}$ & 95 & 96 & 91 & 100 & 93 \\
\hline Ox-AC-BY & 100 & 100 & 94 & 100 & 96 \\
\hline Rd-AC & 98 & 100 & 96 & 100 & 99 \\
\hline Rd-AC-BY & 100 & 100 & 97 & 100 & 99 \\
\hline
\end{tabular}

technique. The data show high recovery percentage from stations (1, 2 and 4) where the percentages of recover were in the range of 70-89, 85-94 and 96-100\%, respectively, by all hybrid AC sorbents (AC-BY, AT-AC, AT-AC-BY, BTAC, BT-AC-BY, Ox-AC, Ox-AC-BY, Rd-AC and Rd-AC-BY). The second run for the same stations were found excellent recovery percentage reaching 80-100, 85-100 and 99-100\%, respectively (Table 5). On the contrary of this trend the higher pollutants area with high concentration of $\mathrm{Hg}$ (5.700 and $4.710 \mu \mathrm{g} / \mathrm{L}$ ) represented by stations (3 and 5) show lower recovery percentage were $42-85$ and 62-89 \%, respectively of recovery by all hybrid AC sorbents (AC-BY, AT-AC, AT-AC-BY, BTAC, BT-AC-BY, Ox-AC, OxAC-BY, Rd-AC and Rd-AC-BY) which considered the lowest recovery percentage done by those sorbents all over tested metal ions or all over tested locations. However this values of recovery show good rising to reach 65-97.0\% and 73-99 \% after 2nd run by all hybrid AC sorbents for these two stations. This data show that all hybrid AC sorbents couldn't reach $100 \%$ of recovery even after second stage of pre-concentration.

The high affinity of $\mathrm{Hg}$ removal enhanced by hybrid $\mathrm{AC}$ sorbents that contained ligand groups (amine, amide, thiol, etc.) from chemical or biological treated can be explained well by the Pearson's theory (Knocke and Hemphill 1981), in which hard acids tend to co-ordinate with hard bases and soft acids with soft bases. Neutral mercury molecules are soft acids, therefore, the interactions of $\mathrm{Hg}$ species such as $\mathrm{HgCl}_{2},\left(\mathrm{HgCl}_{2}\right)_{2}, \mathrm{Hg}(\mathrm{OH})_{2}$ and $\mathrm{HgOHCl}$ with surface nitrogen and sulfur ligands (soft bases) are likely favored. The enhanced $\mathrm{Hg}$ (II) adsorption by hybrid AC may also result from the $\mathrm{Hg}$ reduction and $\mathrm{Hg}(\mathrm{HS})_{2}$ and $\mathrm{Hg}_{2}(\mathrm{HS})_{2}$ formations on sulfur-treated carbons, as suggested by Sinha and Walker (1972) and Lopez-Gonzalez et al. (1982). In an electronic microscopy study, Macias et al. (1995) and Adams (1991) confirmed the presence of $\mathrm{Hg}^{+}$and $\mathrm{Cl}-$ on the surface of activated carbons in contact with $\mathrm{HgCl}_{2}$, supporting the reduction process. In addition, $\mathrm{Hg}$ ions could react with various ligands on the biological treated 
carbon via yeast loaded to form surface complexes. Therefore, a combination of mercury surface reduction, complexation, and/or ion exchange would contribute to the enhanced $\mathrm{Hg}$ sorption by hybrid AC sorbents and biosorbents. This study showed that nitric acid (oxidizing agent) together with sodium sulfite (reducing agent) treatment and ligand groups on the surface of the baker's yeast reaction would effectively in reach Ox-AC, Rd-AC, Ox-AC-BY and $\mathrm{Rd}-\mathrm{AC}-\mathrm{BY}$ to maximum removal percent for all five $\mathrm{Hg}$ contaminated stations.

\section{Conclusion}

The newly designed chemically and/or biologically hybrid activated carbon (AC) sorbents were synthesized as effective sorbents for heavy metals contaminated water in El Mex bay. These sorbents and biosorbents were successfully applied in removing cadmium, lead, chromium and mercury by dynamic micro-column technique. The chemical treatments of commercial active carbon via simple acid, base, oxidation and reduction reactions were found to improve the recovery efficiency of the chemically hybrid AC sorbents for the studied metals than AC blank in all case, this recovery efficiency give excellent values with addition of baker's yeast to all hybrid AC sorbents especially after 2 nd run of micro-column. Reducing active carbon-immobilized-baker's yeast biosorbent (Rd-AC-BY) was characterized by its sorption superiority, under the effect of all studied contaminated areas a long of El-Max bay, compared to the other chemically and biologically immobilized active carbon sorbents and biosorbents, in almost cases Rd-AC-BY get $100 \%$ recovery after only one run of micro-column. Finally, the presented work affords a number of environmental friendly hybrid $\mathrm{AC}$ sorbents and biosorbents characterized by high efficiency of removing different heavy metals from wastewater.

Acknowledgments The authors would like to thank the colleagues in the National Institute of Oceanography and Fisheries for their help and support during the collecting the samples from El Mex Bay.

Open Access This article is distributed under the terms of the Creative Commons Attribution 4.0 International License (http:// creativecommons.org/licenses/by/4.0/), which permits unrestricted use, distribution, and reproduction in any medium, provided you give appropriate credit to the original author(s) and the source, provide a link to the Creative Commons license, and indicate if changes were made.

\section{References}

Abdallah MAM (2008) Trace metal behavior in mediterraneanclimate coastal bay: El-Mex Bay Egypt and its Coastal Environment. Glob J Environ Res 2:23-29
Abdallah MAM (2014) Chromium geochemistry in coastal environment of the Western Harbour, Egypt: water column, suspended matter and sediments. J Coast Conserv 18:1-10

Abdallah MAM, El Sayed NB, Saad M (2007) Distribution and enrichment evaluation of heavy metals in El-Mex Bay using normalization models. Fresenius Environ Bull 16:710-719

Abdel-Fattah TM, Mahmoud ME, Ahmed SB, Huff MD, Lee JW, Kumar S (2014). Biochar from woody biomass for removing metal contaminants and carbon sequestration, J Ind Eng Chem (in press)

Abdullah MI, Royle LG (1974) A study of the dissolved and particulate trace elements in the Bristol Channel. J Mar Biol Assess UK 54:581-597

Adams MD (1991) The mechanism of adsorption of $\mathrm{Hg}(\mathrm{CN}) 2$ and $\mathrm{HgCl} 2$ onto activated carbon. Hydrometallurgy 26:201-210

Baccara R, Bouzida J, Fekib M, Montiela A (2009) Preparation of activated carbon from Tunisian olive-waste cakes and its application for adsorption of heavy metal ions. J Hazard Mater 162:1522-1529

Bag H, Lale M, Turker AR (1998) Determination of iron and nickel by flame atomic absorption spectrophotometry after preconcentration on Saccharomyces cerevisiae immobilized sepiolite. Talanta 47:689-696

Bag H, Turker AR, Lale M, Eli AT (2002) Separation and speciation of $\mathrm{Cr}$ (III) and $\mathrm{Cr}(\mathrm{VI})$ with Saccharomyces cerevisiae immobilized on sepiolite and determination of both species in water by FAAS. Talanta 51:895-902

Cui L, Wang Y, Gao L, Hu L, Yan L, Wei Q, Du B (2015) EDTA functionalized magnetic graphene oxide for removal of $\mathrm{Pb}$ (II), $\mathrm{Hg}$ (II) and $\mathrm{Cu}$ (II) in water treatment: adsorption mechanism and separation property. Chem Eng 281:1-10

El-Rayis OA, Abdallah MAM (2006) Contribution of Some Trace Elements from an Egyptian Huge; the Mediterranean Sea, east of Alexandria. Mediterr Mar Sci 7:79-86

Erdem E, Karapinar N, Donat R (2004) The removal of heavy metal cations by natural zeolites. J Colloid Interface Sci 280:309-314

Faur- Brasquet C, Reddad Z, Kadirvelu K, Le Cloirec P (2002) Modeling the adsorption of metal ions $(\mathrm{Cu} 2+, \mathrm{Ni} 2+, \mathrm{Pb} 2+)$ onto ACCs using surface complexation models. Appl Surf Sci 196:356-365

Fu J, Chen Z, Wu X, Wang M, Wang X, Zhang J, Zhang J, Xu Q (2015) Hollow poly (cyclotriphosphazene-co-phloroglucinol) microspheres: an effective and selective adsorbent for the removal of cationic dyes from aqueous solution. Chem Eng 281:42-52

Grote M, Kettrup A (1985) Ion exchange resins containing S-bonded dithizone and dehydrodithizone as functional groups-II: desorption properties and development of separation procedures for gold and platinum group metals. Anal Chim Acta 175:239

Gupta VK, Agarwal S, Saleh TA (2011) Chromium removal by combining the magnetic properties of iron oxide with adsorption properties of carbon nanotubes. Water Res 45:2207-2212

Imamoglu M, Tekir O (2008) Removal of copper (II) and lead (II) ions from aqueous solutions by adsorption on activated carbon from a new precursor hazelnut husks. Desalination 228:108-113

Knocke WR, Hemphill LH (1981) Mercury (II) sorption by waste rubber. Water Res 15:275-282

Lopez-Gonzalez JD, Moreno-Castilla C, Rodriguez-Reinoso F (1982) Effect of carbon-oxygen and carbon-sulfur surface complexes on the adsorption of mercuric chloride in aqueous solutions by activated carbons. J Chem Technol Biotechnol 32:575-579

Macias GA, Valenzuela CC, Espinosa MAY, Gomezserrano V (1995) Adsorption of $\mathrm{Cd} 2+$ by heat-treated and sulfurized activated carbon. Anal Quim 91:547-552

Mahmoud M, Yakout E, Ahmed SB, Osman MM (2008) Chromium speciation, selective extraction and preconcentration by alumina- 
functionalised 2-pyridenecarboxyladehyde thiosemicarbazone. Int J Environ Anal Chem 88:1017-1031

Mahmoud ME, Hafez OF, Alrefaay A, Osman MM (2010) Performance evaluation of hybrid inorganic/organic adsorbents in removal and preconcentration of heavy metals from drinking and industrial waste water. Desalination 253:9-15

Mahmoud MM, Osman M, Ahmed SB, Abdel-Fattah TM (2011) Improved adsorptive removal of cadmium from water by hybrid chemically and biologically carbonaceous sorbents. ME Chem Eng J 175:84-94

Mahmoud MM, Osman M, Ahmed SB, Abdel-Fattah TM (2012). Enhanced removal of lead by chemically and biologically treated carbonaceous materials. Sci World J 2012

Park SJ, Kim YM (2005) Adsorption behaviors of heavy metal ions onto electrochemically oxidized activated carbon fibers. Mater Sci Eng A 39:121-123

Peez-Corona T, Madrid-Albamin Y, Camara C, Beceiro E (1998) Living organisms as an alternative to hyphenated techniques for metal speciation: evaluation of baker's yeast immobilized on silica gel for Hg speciation. Spectrochim Acta B 53:321-329

Sinha RK, Walker PL (1972) Removal of mercury by sulfurized carbons. Carbon 1:754-756

Tian Y, Yin P, Qu R, Wang C, Zheng H, Yu Z (2010) Removal of transition metal ions from aqueous solutions by adsorption using a novel hybrid material silica gel chemically modified by tri ethylene tetramino methylene phosphonic acid. Chem Eng J 162:573-579

United Nations Environment Programme (UNEP) (1993). United Nations Environment Programme, report of the governing council seventeenth session. Supplement No. 25 (A/48/25). New York pp 96

Vasudevan P, Padmavathy V, Dhingra SD (2002) Biosorption of monovalent and divalent ions on baker's yeast. Bioresour Technol 82:285-289

Yavuz H, Denizli A, Gungunes H, Safarikova M, Safarik I (2006) Biosorption of mercury on magnetically modified yeast cells. Sep Purif Technol 52:253-260 